\title{
Front Line Demonstrations on Need Based Plant Protection in the Important Solanaceous Vegetables Impact in Enhancing Productivity And Profitability Under Farmers' Field In Keonjhar District Of Odisha.
}

\author{
Prasanta kumar Nanda ${ }^{1}$ and Poly Saha ${ }^{2}$ \\ ${ }^{1}$ KVK, Keonjhar, Orissa University of Agriculture and Technology, Odisha -758002, India \\ ${ }^{2}$ RRTTS, Keonjhar, Orissa University of Agriculture and Technology, Odisha -758002, India
}

\begin{abstract}
One of the major reasons of low productivity insolanaceous vegetables is the lack of technical knowledge of the farmers about judicious andtimely implementation of the management strategies against the major biotic stresses (insect pests and diseases)which ultimately reduce its return. Considering the fact front line demonstrations on need based plant protection in solanaceousvegetables were conducted in farmers' fields at different villages of the Keonjhar district, under north eastern plateau zones of odisha, during 2011-12 and 2012-13 to show the productivity potential and profitability of Improved Technologies (IT). The results recorded higher mean productivity ranges from $19.7 \%$ to $38 \%$, gross returns, additional net return, B: C ratio and ICBR value ranges from 6.4 for need based plant protection in solanaceous vegetables to 13.6 in the IT plots than the farmers' practice plots indicating the technical and economic feasibility of IT over FP(Farmers Practices).
\end{abstract}

Key Words: Farmers'practices (FP), FLDs, Improved practices (IP), Profitability and Solanaceousvegetables.

\section{Introduction}

The term "solanaceous crops" generally refers to plants in the nightshade family, Solanaceae, within the Generamost important vegetables include Capsicum (peppers), Lycopersicon (tomato), Solanum(eggplant and potato)andAbelmoschus(okra/bhendi). The solanaceous vegetables cover largest area and play an important role in total vegetable production in India. Odisha is one of the vegetable growing state of the country occupies total 0.37 mhaunder solanaceous vegetable with production of 42.90 (lakh MT). Out of this brinjal share 35\%, okra 19\%, tomato 23\% and chilli 21\% (Source: Horticulture in Odisha,2013). The productivity of these four vegetables i.e. brinjal, okra, tomato and chilli are $16.77 \mathrm{q} \mathrm{ha}^{-1}, 8.82 \mathrm{q} \mathrm{ha}^{-1}, 14.19 \mathrm{q} \mathrm{ha}^{-1}$ and $0.96 \mathrm{q} \mathrm{ha}^{-1}$ respectively. In keonjhar only 30 ('000 ha) area are under solanaceous vegetable cultivation but the productivity is slightly higher over the state with total production 4.02 (lakh MT) (Source: Horticulture in Odisha,2013).

Now most of the solanaceous vegetables are available throghout the year. However, there is a risk of severe damage by insect pests and diseases. Particularly,the insects that damage these crops range in their ability to reduce yieldsat different growth stages.Morever, insects that transmit disease agents, such as whitefly or thrips vectored plant viruses, can also have similar devastating effects on yield. Vulnerability of the solanaceous vegetables to insect pests and diseases continues to be one of the major factors responsible for the lower productivity with wider fluctuation (Rabindraet al. 2007[1]).

Considering the changing scenario in demand of vegetables, there is further need for increasing productivity and profitability along with the quality vegetables production in the country. There is a potential to increase production of solanaceous vegetables by using best production practices and right combination of input at right time (Kumar and Chauhan, 2007[2]) to bridge the yield gap between demonstration trials and farmer's field. Several technologies and management options are developed for protecting the crops, that can significantly reduce the losses due to insect pests, but adoption of these technologies by the farmers has been far less than anticipated. Realizing the importance of extending these technologies for management insect pests in solanaceous vegetables at farmers' level, frontline demonstrations (FLDs) were conducted to show the productivity potential and profitability of need based plant protection.

\section{Materials And Methods}

The improved technology (IT), i.e need based plant protection included use of pheromone trap, neem oil and prophylactic spray with biological and safer pesticides as and when required based on nature of pest and its damage symptoms. The IT was demonstrated in comparison with the farmers practice (FP) of no spraying/indiscriminate use of pesticide, in order to provide farmers an opportunity to compare, evaluate and choose themselves the best practise based on their own criteria. The details of IT are presented inTable1. The FLDs conducted at Keonjhar district of Odisha during 2011-12 and 2012-13on four major solanaceous crops and most prevalent insects in this region were considered and natural epiphytotic condition allowed. A total of 
40 FLDs were demonstrated to calculate the potential benefit of IT. The data on yield cost of cultivation and gross monetary returns were collected from IT plots and FP plots. The improvement in yield was estimated by the following formula.

Improvement in yield $(\%)=$ Yield gain in IT plot $(q)$ - yield gain in FP plot(q)/ yield gain in FP plot (q) X 100

Table 1. Crop wise target insect pests and IT demonstrated.

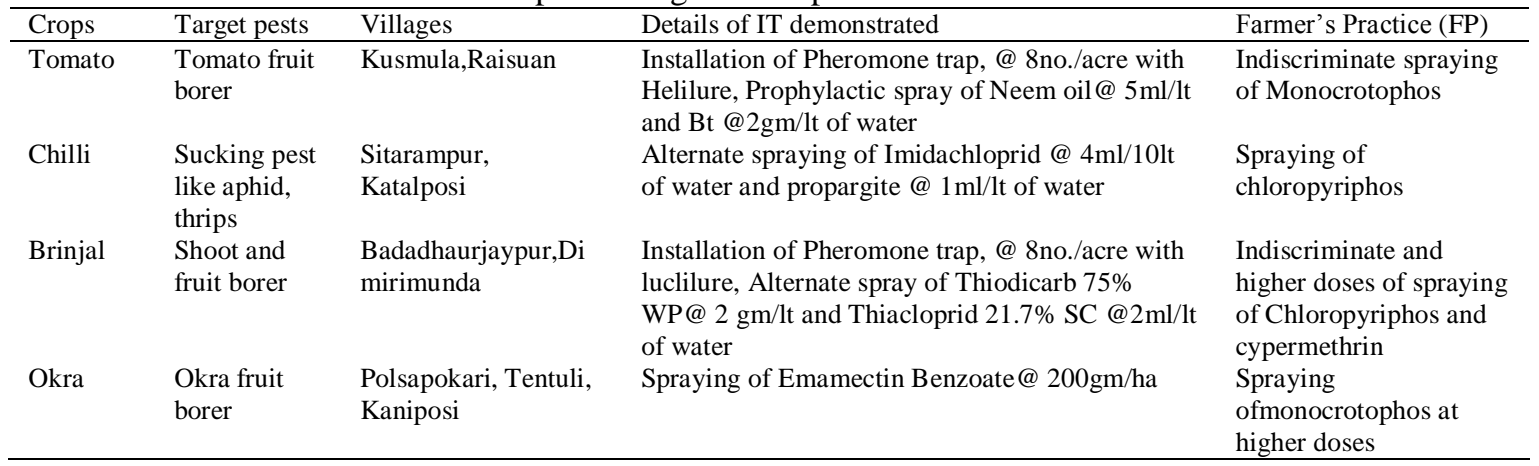

Partial budgeting technique (Birthal, 2003 [3]) was used to estimate additional net return, cost benefit ratio (B:C ratio) and incremental cost benefit ratio (ICBR) of the demonstration. The technology is economically feasible if the profits are higher compared to those farmers' practice. This could be symbolically represented as follows:

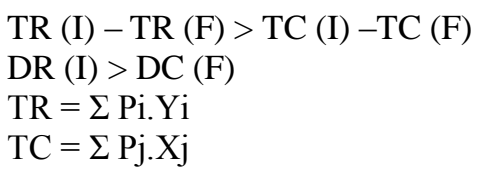

Where, TR $(\mathrm{F})=$ Total returns from farmers' practice plot; TC $(\mathrm{F})=$ Total cost recorded in farmers' practice plot; DR $(\mathrm{I})=$ Change in the revenue due to improved technology; $\mathrm{DC}(\mathrm{F})=$ Change in the revenue due to farmers' practice; TR (I) = Total return from the improved technology plot; TC(I) = Total cost from the improved technology plot; $\mathrm{Pi}=$ Price of the $\mathrm{i}^{\text {th }}$ output $(\mathrm{i}=1, \ldots, \mathrm{n}) ; \mathrm{Yi}=$ quantity of the $\mathrm{i}^{\text {th }}$ output $(\mathrm{i}=1, \ldots, \mathrm{n}) ; \mathrm{Pj}$ $=$ Price of the $\mathrm{j}^{\text {th }}$ input $(\mathrm{j}=1, \ldots, \mathrm{n})$ and $\mathrm{Xj}=$ quantity of the $\mathrm{j}^{\text {th }}$ input $(\mathrm{j}=1, \ldots, \mathrm{n})$.

\subsection{Performance of FLD on productivity potential}

\section{Results And Discussion}

A comparison of productivity levels between improved practices in demonstration trials and farmers' practices is shown in Table 2. The results recorded the percentage increase in yield in IT plots over FP was $38.02 \%$ in Brinjal followed by $29.6 \%$ in Chilli, $28.82 \%$ in Okra and $19.7 \%$ in Tomato (Table 2). The productivity improvements were observed in all the crops tested in IT plots as compared to the FP plots. Singh et al. (2011) [4] reported increase in yield $28.22 \%$ in tomato, $29.17 \%$ chilli and $21.43 \%$ in brinjal in Rajasthan condition through FLDs on improved production technology. Raiet al. (2005)[5] also showed increase of productivity in tomato, brinjal and chilli due to adoption of improved varieties by the farmers' of eastern Uttar Pradesh through FLDs in the farmers' field. Afzal Ahmed et al. (2013) [6] observed 21.7\% increase in seed yield in FLD plots due to management of aphid and Alternaria blight in Indian mustard.

Table 2. Productivity potential of need based plant protection in solanaceous vegetables at Keonjhar district of Odisha during 2011-13

\begin{tabular}{lcccc}
\hline \multirow{1}{*}{ Crop } & No. Of Demonstrations & \multicolumn{2}{c}{ Mean yield(q/ha)* } & \multicolumn{2}{c}{ Increase in yield over } \\
\cline { 3 - 3 } & & FP $(\%)$ & 19.70 \\
\hline Tomato & 10 & 318.0 & 265.6 & 29.60 \\
Chilli & 10 & 127.8 & 98.6 & 38.02 \\
Brinjal & 10 & 412.0 & 298.5 & 28.82 \\
Okra & 10 & 191.3 & 148.5 & \\
\hline
\end{tabular}

Averaged across the demonstrated villages for each crop, IT = Improved Technology, FP = Farmers Practice 
Table 3. Economic returns due to need based plant protection in solanaceous vegetables at Keonjhar district of Odisha during 2011-13

\begin{tabular}{|c|c|c|c|c|c|c|c|c|c|c|c|}
\hline \multirow[b]{2}{*}{ Crops } & \multicolumn{2}{|c|}{ CoC(Rs./ha) } & \multirow[t]{2}{*}{$\begin{array}{l}\text { Increase } \\
\text { over } \\
\operatorname{FP}(\%)\end{array}$} & \multicolumn{2}{|c|}{ GMR(Rs./ha) } & \multirow[t]{2}{*}{$\begin{array}{l}\text { Increase } \\
\text { over } \\
\operatorname{FP}(\%)\end{array}$} & \multirow{2}{*}{$\begin{array}{l}\text { APP } \\
\text { (Rs./ha) }\end{array}$} & \multirow{2}{*}{$\begin{array}{l}\text { ANR } \\
\text { (Rs.) }\end{array}$} & \multicolumn{2}{|c|}{$\mathrm{B}: \mathrm{C}$ ratio } & \multirow[b]{2}{*}{ ICBR } \\
\hline & IT & FP & & IT & FP & & & & IT & FP & \\
\hline Tomato & 51400 & 48300 & 6.4 & 159000 & 132800 & 19.7 & 3100 & 23100 & 3.1 & 2.7 & 8.5 \\
\hline Chilli & 49800 & 47000 & 5.9 & 115020 & 88740 & 29.6 & 2800 & 23480 & 2.3 & 1.8 & 9.4 \\
\hline Brinjal & 73200 & 62500 & 17.1 & 247200 & 179100 & 38.0 & 10700 & 57400 & 3.8 & 2.9 & 6.4 \\
\hline Okra & 55400 & 53200 & 4.13 & 133910 & 103950 & 28.8 & 2200 & 27760 & 2.4 & 1.9 & 13.6 \\
\hline
\end{tabular}

$\mathrm{CoC}=$ Cost of cultivation; GMR = Gross monetary returns; $\mathrm{APP}=$ Additional cost on plant protection; $\mathrm{ANR}=$ Additional net returns; ICBR = Incremental cost benefit ratio.

\subsection{Economic Analysis}

The economics of solanaceous vegetable production under frontline demonstration were estimated and the results have been presented in Table 3. The cost of cultivation increased maximum $17.1 \%$ in case of brinjalwith IT as compared to FP followed by tomato $6.4 \%$. The comparative profitability of different solanaceous vegetable also revealed that among them brinjal produce maximum gross as well as net return i.eRs. 2,47,200 ha ${ }^{-1}$ and Rs. 57,400 ha ${ }^{-1}$ respectively which might be due to higher market price, longer fruiting period and profitable over other crops and lowest gross return was recorded in chilli. This results are in accordance with the findings of Sharma (2003) [7], Hiremath and Nagaraju (2009) [8]and Singh et al. (2011) [4].In consequence, gross monetary return (GMR) increased by $38 \%$ and $29.6 \%$ in brinjal and chilli respectively indicating the importance of need based plant protection. The higher GMR realised by the farmers indicate the economic feasibility of the technology. The additional net return (ANR), which is the true indicator of economic worth of the practice was at Rs. $57,400 \mathrm{ha}^{-1}$ for brinjal followed by okra Rs. 27,760 ha ${ }^{-1}$, Chilli Rs. 23,480 ha ${ }^{-1}$ and tomato Rs. $23100 \mathrm{ha}^{-1}$. The data presented in Table 3 also revealed the expenditure involved in the demonstrated plot is higher than the farmers' field due to additional cost involved for plant protection (APP) but the yield obtained is also higher in the demonstrated plot that is confirmed by the comparative result obtained by calculating the cost benefit ratio. In all the cases, B:C ratio is higher in IT plots as compared to FP and maximum recorded in brinjal 3.8 in IT against 2.9 in FP. The incremental cost-benefit ratio (ICBR) was 13.6 and 9.4 for okra and chilli respectively, indicating a good return of around Rs. 14 and Rs. 9 for each additional rupee invested on IT for okra and chilli separately. Sharma and Lijo Thomas (2013) [9] calculated the ICBR value ranged from 3.2 for plant disease management to 6.2 in case of pest management technology in rapeseedmustard. Kumar et al. (2014) [10] recorded ICBR value 3.1 to 10.3 for need based plant protection in oilseed under rainfed and irrigated condition through FLD.

\section{Conclusion}

Frontline demonstration is the most suitable method for assessing the performance of the improved technology as it directly involves the scientists in conducting the demonstrations at the farmers' field which enables them to have first hand information related to the technology. The FLDs conducted in Keonjhar district of Odisha on solanaceous vegetables showed the potential of IT (need based plant protection) to step up the productivity significantly by reducing losses due to insect pests and increasing the income of farmers. It is estimated that the solanaceous vegetable production can be improved $20-38 \%$ by effective management of insect pest.

In order to scale-up the demonstration and speed up the dissemination of plant protection technologies there should be a multi-pronged strategy of educating the farmers on identifying the damaged symptoms of various insect pest including diseases of the solanaceous vegetables, identifying the suitable time and stage of the crop for taking management strategies and ensuring timely availability of quality inputs (chemical and biological) will go a long way in preventing the losses from biotic stresses and definitely enhance its production and productivity.

\section{References}

[1]. R.J. Rabindra, SunilJoshi, and K. Veenakumari, Biological control of insect pests of oilseeds in India, In changing global vegetable oil scenario: Issue and challenges before India (Ed Hedge DM), Indian Society of Oilseeds Research, Hyderabad,2007,101-142.

[2]. S. Kumar, and S. Chauhan, Production performance and total factor productivity growth oil seeds in India, In changing global vegetable oil scenario: Issue and challenges before India (Ed Hedge DM), Indian Society of Oilseeds Research, Hyderabad,2007, 239-246.

[3]. P.S. Birthal, Economic potential of biological substitutes for agrochemicals, Policy Paper, 18, National centre for Agricultural Economics and Policy Research, New Delhi, 2003. 
[4]. Ranjeet Singh, R.L. Soni, Virendra Singh, and H.L. Bugalia, Dissemination of improved production technologies of solanaceous vegetables in Banswara district of Rajasthan through frontline demonstrations, Rajasthan Journal of Extension Education, 19, 2011, $97-100$.

[5]. Mathura Rai, Neeraj Singh, B. Singh, and Major Singh, Performance of improved varieties of solanaceous vegetable crops at farmers' field in eastern Uttar Pradesh, Vegetable Science, 32(1), 2005, 69-72.

[6]. AfzalAhmed, GuruPrem, and Ramesh Kumar, Impact of Frontline Demonstrations on Indian Mustard through Improved Technologies, India Research Journal of Extension Education, 13, 2013, 117-119.

[7]. O.P. Sharma, Moth bean yield improvement through frontline demonstrations, Agril Extension Review, 15 (5),2003, 11-13.

[8]. S.M. Hiremath, and M.V.Nagaraju, Evaluation of frontline demonstration trials on onion in Haveri district of Karnataka,Karnataka Journal of Agriculture Science, 22 (5), 2009, 1092-1093.

[9]. A.K. Sharma, and Lijo Thomas, Technology inputs and its impact on Farm Profit: A case study of Rapeseed-Mustard,Indian Research Journal of Extension Education,13, 2013,9-14.

[10]. G.D.S. Kumar, M. Padmaiah, and S.V. RamanaRao, Frontline demonstrations on need based plant protection in oilseeds: impact in enhancing productivity and profitability under farmers' condition,Indian Journal of Plant Protection, 42 (2), 2014, 105-109. 